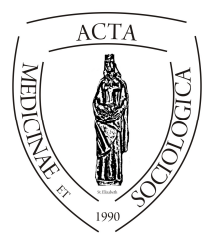

\title{
Az egészségügyi tevékenységhez kapcsolódó felelősségi formák rendszere különös tekintettel a foglalkozás körében elkövetett veszélyeztetésre
}

\author{
Kiss János Márk \\ III. évf. doktorandusz, DE Marton Géza Állam- és Jogtudományi Doktori Iskola, 4032 Debrecen, Egyetem tér 1.,
}

\begin{tabular}{ll}
\hline \multicolumn{1}{c}{ INFO } & \multicolumn{1}{c}{ ABSTRACT } \\
\hline János Márk Kiss \\
kissjanosm@gmail.com & $\begin{array}{l}\text { The types of responsibility related to health care activities } \\
\text { with special attention to professional misconduct. Medical } \\
\text { practice affects human life and health that are not just one of } \\
\text { the key social values, they also incorporate the existence of a } \\
\text { Keywords } \\
\text { human being. Therefore, it is required to set the rules for } \\
\text { professional misconduct, } \\
\text { criminal law, } \\
\text { liability considering the nature of professional norms on } \\
\text { medicine and the protection of human life and health. A } \\
\text { regulation in this area presumes a complex system of liability } \\
\text { rules. This is the reason medical malpractice might call for } \\
\text { various types of legal liabilities, such as tort liability and } \\
\text { criminal liability. } \\
\text { Constitutional provisions relating to the protection of hu- } \\
\text { man life and health require specific provisions for medical } \\
\text { malpractice in the Criminal Code. Although healthcare } \\
\text { employees, especially physicians are highly qualified } \\
\text { professionals, almost all types of medical treatment involve } \\
\text { serious risks. Therefore, the violation of professional rules } \\
\text { and failing to provide the standard of care must be penalized. } \\
\text { The Hungarian Criminal Code contains several } \\
\text { provisions related to medical malpractice. Most of them are } \\
\text { related to bioethics. The violation of the professional rules is } \\
\text { criminalized by Article 165 of the Criminal Code under the } \\
\text { crime of endangerment committed as a professional. Unlike } \\
\text { the rest of the medicine-related provisions, this section of the } \\
\text { code only applies if the subject's negligence puts the victim's } \\
\text { - in this case the patient's - life into danger or causes him } \\
\text { injury. The legal base of liability here is the same as it is in } \\
\text { tort law, so it can be stated that this provision fits better to the } \\
\text { liability system of the medical practice than the bioethics- } \\
\text { related crimes. } \\
\text { The purpose of this study is to provide a review of the } \\
\text { criminal law aspect on the medical liability system. }\end{array}$ \\
\hline
\end{tabular}




Kulcsszavak
foglalkozás körében el-
követett veszélyeztetés,
orvosi felelősség,
orvosi mühiba,
egészségügyi dolgozók
felelőssége

Kulcsszavak

foglalkozás körében elkövetett veszélyeztetés, orvosi felelösség, orvosi mühiba, felelőssége

\begin{abstract}
Absztrakt. Az általános felfogás szerint a jog a társadalom minimális morális értékeit határozza meg. ${ }^{1} \mathrm{E}$ rendeltetését alapvetően úgy tölti be, hogy meghatározott helyzetekre meghatározott magatartásfajtákat ír elö, amelyek nem-tanúsítása esetére szankciókat helyez kilátásba, és biztosítja azok állami úton való kikényszeríthetőségét. ${ }^{2} \mathrm{Az}$ egészségügyi tevékenység az emberi életet, testi épséget, illetve egészséget érinti, melyek nem pusztán kiemelt társadalmi értékek, hanem az emberiség egzisztenciájának alapját jelentik, ezért az állam nagyfokú aktivitására, illetve kiterjedt jogi szabályozásra van szükség ezen a területen. A szerteágazó szabályozás összetett felelősségi rendszert feltételez, így az egészségügyi tevékenység végzése során bekövetkező jogsértés esetén a jogi felelősség négy alaptípusa - Eörsi Gyula nyomán: büntetőjogi, államigazgatási jogi, munkajogi, valamint polgári jogi felelősség $^{3}$ - közül három, illetve ezek mellett egy további, az etikai felelösség is szóba jöhet.

$A z$ emberi élet, testi épség és testi épség érintettsége felveti az egészségügyi tevékenységgel kapcsolatos speciális büntetőjogi tényállások kidolgozásának szükségességét is. Az egészségügyi foglalkozások, különösen az orvosi hivatás, amellett, hogy nagy társadalmi presztízzsel bír, magas képzettséget igényel. A gyógyító tevékenység viszont akkor is megában hordozza a beteg károsodásának, illetve halálnak veszélyét, ha az ellátásban résztvevő személyek birtokában vannak szükséges kvalitásoknak. E hivatás gyakorlása során a tevékenység gyakorlása a során mérvadó gondossági mérce, illetve a szakmai szabályok betartását egy, az e tevékenység sajátosságaira szabott, büntető törvénykönyvbeli tényállás útján lehet csak megfelelően biztosítani.

A hatályos Btk. ${ }^{4}$ számos olyan tényállást rögzít, amely kapcsolódik, illetve kapcsolódhat az egészségügyi tevékenységhez. Az egészségügyi ellátásban részt vevő személyek tekintetében irányadó szakmai szabályok megszegésének büntetőjogi fenyegetettségét a Btk. 165. § szerinti foglalkozás körében elkövetett veszélyeztetés tényállása teremti meg. Mivel a fent említett magánjogi, illetve etikai normák alapján történő felelősségre vonás többnyire szintén a szakmai követelmények megszegése esetén merülhet fel, a büntetőjog arzenáljából ez kapcsolódik a legszorosabban az előbbi felelősségi formákhoz, illetve egyedül ez illeszkedik az egészségügyi tevékenységhez kapcsolódó felelősség rendszerébe.
\end{abstract}

\footnotetext{
${ }^{1}$ Sándor Judit: Gyógyítás és ítélkezés, Budapest, Medicina, 1997., 41.

${ }^{2}$ Eörsi Gyula: A jogi felelősség alapproblémái, a polgári jogi felelősség, Budapest, Akadémiai Kiadó, 1961., 21.

${ }^{3}$ Eörsi: i.m. 206.

${ }^{4}$ A Büntető Törvénykönyvről szóló 2012. évi C. törvény (Btk.)
} 
A tanulmány célja, a foglalkozás körében elkövetett veszélyeztetés Btk.-beli tényállásának - az egészségügyi ellátásban résztvevők vonatkozásaira szorítkozva történő - elemzésével bemutassa a büntetőjogi felelősség szerepét az egészségügyi tevékenység felelösségi rendszerében.

Ez a tanulmány a Magyar Tudomány Ünnepén („Ember a társadalomban és az egészségügyben” - 2017. 11. 29., Debreceni Egyetem Egészségügyi Kar) elhangzott előadás alapján készült.

\section{Bevezető gondolatok}

Annak, hogy az ember társas lény, következménye, hogy az individualitással, és konformitással társult értékek közötti feszültség állapotában élünk. ${ }^{5} \mathrm{E}$ feszültség feloldása a társas együttélés minimális követelményeinek lefektetése útján lehetséges. Éppen ezért már az ôsi társadalmak is rendelkeztek valamiféle normarendszerrel, melyek azonban nem müködhetnek az egyes szabályok megszegéséért való helytállás kikényszeríthetősége nélkül, így a szabályozással egyidejüleg a hozzájuk kapcsolódó felelősségi rendszerek is létrejöttek.

A huszadik század második feléig az orvosok tekintetében ez meglehetősen sajátosan alakult, eddig ugyanis a beteg az orvos tevékenységének passzív résztvevője volt, ha a beavatkozás nem járt sikerrel, esetleg a beteg halálához vezetett, az orvost nem - azaz a korai gyakorlatról rendelkezésre álló ismeretek alapján igencsak szük körben - lehetett felelősségre vonni, hiszen - a közfelfogás szerint - a kezeléssel az orvos „maximálisan jót akart”. ${ }^{6}$ Mára azonban az orvosok, illetve egészségügyi ellátásban résztvevők felelőssége meglehetősen szerteágazó kategóriává vált. A XX. második feléig jobbára az orvosetikai normák jelentették az orvoslás jogát. ${ }^{7}$ Napjainkban azonban a modern orvostudomány vívmányai és az átalakult társadalmi viszonyok megkövetelik az egészségügyi szolgáltatások nyújtásának és igénybevételének jogszabályi úton történő szabályozását.

Az általános felfogás szerint a jog a társadalom minimális morális értékeit határozza meg. ${ }^{8}$ E rendeltetését alapvetően úgy tölti be, hogy meghatározott helyzetekre meghatározott magatartásfajtákat ír elő, amelyek nem-tanúsítása esetére szankciókat helyez kilátásba, és biztosítja azok állami úton való kikényszeríthetőségét. ${ }^{9}$ Az egészségügyi tevékenység az emberi életet, testi épséget, illetve egészséget érinti, melyek nem pusztán kiemelt társadalmi értékek, hanem az emberiség egzisztenciájának alapját jelentik, ezért az állam nagyfokú aktivitására, illetve kiterjedt jogi szabályozásra

${ }^{5}$ Elliot Aronson: A társas lény, Budapest, KJK, 2001. 33. o.

${ }^{6}$ Jobbágyi Gábor: Orvosi jog, Szent István Társulat, Budapest, 2010. 23. o.

7 Jobbágyi Gábor: i.m. 21. o.

${ }^{8}$ Sándor Judit: Gyógyítás és ítélkezés, Budapest, Medicina, 1997., 41. o.

${ }^{9}$ Eörsi Gyula: A jogi felelősség alapproblémái, a polgári jogi felelősség, Budapest, Akadémiai Kiadó, 1961., 21. o. 
van szükség ezen a területen. A szerteágazó szabályozás összetett felelősségi rendszert feltételez, így az egészségügyi tevékenység végzése során bekövetkező jogsértés esetén a jogi felelősség négy alaptípusa - Eörsi Gyula nyomán: büntetőjogi, államigazgatási jogi, munkajogi, valamint polgári jogi felelősség ${ }^{10}$ - közül három, illetve ezek mellett egy további, az etikai felelösség is szóba jöhet.

Az emberi élet, testi épség és testi épség érintettsége felveti az egészségügyi tevékenységgel kapcsolatos speciális büntetőjogi tényállások kidolgozásának szükségességét is. Az egészségügyi foglalkozások, különösen az orvosi hivatás, amellett, hogy nagy társadalmi presztízzsel bír, magas képzettséget igényel. A gyógyító tevékenység viszont akkor is megában hordozza a beteg károsodásának, illetve halálnak veszélyét, ha az ellátásban résztvevő személyek birtokában vannak a szükséges kvalitásoknak, így e hivatás gyakorlása során a tevékenységgel összefüggésben irányadó gondossági mérce, illetve a szakmai szabályok betartását egy, az e tevékenység sajátosságaira szabott, büntető törvénykönyvbeli tényállás útján lehet csak megfelelően biztosítani. A hatályos Btk. ${ }^{11}$ számos olyan tényállást rögzít, amely kapcsolódik, illetve kapcsolódhat az egészségügyi tevékenységhez. Az egészségügyi ellátásban részt vevő személyek tekintetében irányadó szakmai szabályok megszegésének büntetőjogi fenyegetettségét a Btk. 165. § szerinti foglalkozás körében elkövetett veszélyeztetés tényállása teremti meg. Mivel a fent említett magánjogi, illetve etikai normák alapján történő felelősségre vonás többnyire szintén a szakmai követelmények megszegése esetén merülhet fel, a büntetőjog arzenáljából ez kapcsolódik a legszorosabban az előbbi felelősségi formákhoz, illetve egyedül ez illeszkedik az egészségügyi tevékenységhez kapcsolódó felelősség rendszerébe.

Jelen tanulmány célja, a foglalkozás körében elkövetett veszélyeztetés Btk.-beli tényállásának - az egészségügyi ellátásban résztvevők vonatkozásaira szorítkozva történő - elemzésével bemutassa a büntetőjogi felelősség szerepét az egészségügyi tevékenység felelősségi rendszerében.

\section{Az egészségügyi tevékenységhez kapcsolódó fele- lősségi szabályok rendszere}

Amint az a bevezetőben is említésre került, az egészségügyi dolgozók, illetve az egészségügyi szolgáltatók felelőssége többféle jogi alapon is felmerülhet. Az egészségügyi szolgáltatás nyújtása során elkövetett szakmai szabályszegés, illetve ezzel összefüggésben a beteg egészségkárosodása - bár egyetlen cselekményről van szó egyidejűleg több alany felelősségét is megalapozhatja, különböző jogszabályi rendelkezések, illetve egyéb normák alapján, különböző személyekkel szemben, önálló eljárások keretei között, eltérő jogkövetkezményekkel.

A lakosság és az egyén egészségégének, illetve jóllétének, mint az állampolgárok életminőségének és önmegvalósításának alapvető feltételének megteremtése és vé-

${ }^{10}$ Eörsi: i.m. 206. o.

${ }^{11}$ A Büntető Törvénykönyvről szóló 2012. évi C. törvény (Btk.) 
delme aktív és mélyreható állami szerepvállalást követel meg. Az egészségügyi tevékenység végzéséhez szükséges szakmai feltételeinek és az ellátás megfelelő színvonalát biztosítani képes garanciákat csak egy, a teljes ágazatra kiterjedö, valamennyi egészségügyi dolgozót érintő, átfogó közjogi szabályozás keretei között lehet lefektetni. ${ }^{12}$

Az egészségügyi tevékenységet érintő jogi szabályozás rendszere nem szükíthető le az ágazati jogszabályok összességére, más jogterületek is figyelembe jönnek, a sajátos felelősségi szabályaikkal együtt.

\section{Kártérítés és személyiségvédelem: az egészségügyi szolgáltató és az egészség- ügyi dolgozó felelőssége az egészségügyi szolgáltatással összefüggésben oko- zott kárért.}

Az egészségügyi szolgáltatás sajátosságaira, különösen az annak tárgyát képező emberi élet, testi épség és egészség triászára, mint - mind a társadalom, mind pedig az egyén szempontjából - kiemelten védendő értékekre tekintettel az ellátás nyújtására irányuló jogviszonyban a beteget megillető jogoknak, valamint a szolgáltatást nyújtó felet terhelö kötelezettségeknek olyan fokú autonómiát kell biztosítaniuk elsősorban - a beteg számára, amely kizárólag polgári jogi keretek között lehetséges. Az emberi test fizikai integritása ugyanis kihat a teljes személyiségre, az élethez, testi épséghez és egészséghez való jog ezért a legalapvetőbb személyiségi jogok egyike, amelyet érintő beavatkozás felett az egyénnek a lehető legszélesebb körü kontrollal kell rendelkeznie. Az ennek megfelelő autonómia pedig kizárólag magánjogi keretek között biztosítható.

Éppen ezért Európa szerte egységes a tudományos és a gyakorlati álláspont a tekintetben, hogy az egészségügyi szolgáltató és a beteg között létrejövő, az egészségügyi szolgáltatás nyújtására, illetve igénybevételére irányuló jogviszony polgári jogi szerződéses kötelék, amelyben a felek autonómok, egyenjogúak és mellérendeltek. ${ }^{13}$ Amenynyiben tehát a beteg nem jut hozzá a fenti jogviszonyban őt megillető jogosultságok szerint neki járó egészségügyi szolgáltatáshoz, illetve ezzel összefüggésben kárt szenved, a polgári jog eszközeivel léphet fel az egészségügyi szolgáltatóval szemben.

Bár az egészségügyi ellátás során irányadó szakmai szabályok a fenti szerződéses jogviszonyból eredő, a teljesítés mikéntjére vonatkozó kötelezettségként is felfoghatók, nem eshetnek a fogyasztói szerződésekben szereplő szolgáltató kötelezettségeivel azonos megítélés alá. Ezek ugyanis nem az egészségügyi szolgáltatást igénybe vevő fogyasztó vagyoni érdekeit védik, hanem a beteg, mint ember személyiségét. Ennek megfelelően a megsértésükhöz füződő felelősség is eltérően alakul: a fogyasztói szerződésből eredő szavatossági igények (kijavítás, kicserélés) érvényesítésével kapcsolatos szabályok az egészségügyi szolgáltatásokkal összefüggésben csak szük körben vagy egyáltalán nem alkalmazhatók. A szakmai szabályok megszegése tehát az ezzel

\footnotetext{
${ }^{12}$ Megjegyzendő, hogy az Eütv. 3. § d) pontja az egészségügyi tevékenységben közremüködő, egészségügyi szakképesítéssel nem rendelkező személyeket is egészségügyi dolgozónak tekinti, így az egészségügyi szolgáltatással összefüggésben - bizonyos körben - a szakképzettséggel nem rendelkező dolgozók felelőssége is felmerülhet. Tekintettel azonban arra, hogy az egészségügyi szolgáltatások sajátosságai okán a szakképzettséggel rendelkező egészségügyi dolgozók felelősségi szabályainak eltérései bírnak gyakorlati jelentőséggel, e tanulmány nem tér ki az egészségügyi dolgozók fent említett csoportjával kapcsolatos szabályozásra.

13 Jobbágyi: i.m. 37. o.
} 
összefüggésben felmerült vagyoni és személyiségi jogi sérelmek kompenzációjára vonatkozó kötelezettséget alapozhatja meg.

A hazai szabályozás nem kezeli sui generis szerződéstípusként az egészségügyi szolgáltatás nyújtására irányuló szerződést, a bírói gyakorlat ${ }^{14}$ azonban egyöntetű a tekintetben, hogy az egészségügyi szolgáltatás igénybevétele szerződéses keretek között történik. Az egészségügyi szolgáltatásokkal összefüggésben keletkezett kár-, illetve sérelemdíj-igényeket nem a szerződésszegésre vonatkozó, hanem a Ptk.-nak ${ }^{15}$ a szerződésen kívül okozott kárért való felelősségre, valamint a személyiségi jogok megsértésének szankcióira vonatkozó szabályai szerint kell elbírálni. ${ }^{16} \mathrm{~A}$ Ptk. objektivizált kontraktuális felelősségi konstrukciójának ${ }^{17}$ az egészségügyi szolgáltatással összefüggésben okozott károkért való felelősség megítélése során történő alkalmazása ugyanis - a jogviszony sajátosságait figyelembe véve - ellentétes lett volna a jogalkotói szándékkal, jelesül azzal, hogy a szerződésszegésért való felelősség szabályai az üzleti élet szereplöihez, illetve jogviszonyaihoz igazodjanak. ${ }^{18}$

Bár az egészségügyi beavatkozás során történt károkozás esetén általában az egészségügyi szolgáltatót terheli kártérítési felelősség, ${ }^{19}$ a károkozó cselekmény minden esetben emberi tevékenység által valósul meg. A régi $\mathrm{Ptk}^{20}{ }^{20}$ utaló szabálya ${ }^{21}$ alapján az alkalmazott által okozott kár munkáltató általi megtérítése esetén utóbbi regressz igénye a munkajog szabályai szerint alakul. Bár a hatályos Ptk. már nem utal rá kifejezetten, ennek ellenére munkavállalói károkozásról lévén szó, továbbra is az Mt. $^{22} 179$. § szabályait kell alkalmazni.

\section{Etikai felelősség az egészségügyben}

Az etika erkölcsi elvei a jogi szabályozáshoz hasonlóan szintén magatartási szabályok, amelyek azonban nélkülözik az állami beavatkozás útján való kikényszeríthetöséget, mely a jogszabályban rögzített erkölcsi alapelvek érvényesülését biztosítja. Felmerül tehát a kérdés, hogy a szerteágazó jogi szabályozás mellett milyen szerepet tölt be napjainkban az orvosi etika, illetve az etikai felelősség.

Az orvosi etika évezredes múltra visszatekintő elvei napjainkra beépültek a jogi szabályozásba, ennek ellenére ma is léteznek a jogi szabályozástól elkülönült hivatásetikai szabályok. Az egészségügyi tevékenység specialitásai teszik indokolttá egy sajátos belső normarendszer fenntartását. Az orvosi etika ugyanis - az általános erkölcsi alapelvek mellett - szoros kapcsolatban áll az orvostudománnyal. Szabályai nem a

\footnotetext{
${ }^{14}$ BDT 2008.1755., BDT 2009.1944., BDT 2016.3445. stb.

15 a Polgári Törvénykövről szóló 2013. évi V. törvény (Ptk.)

${ }^{16}$ Eütv. 244. $\S(2)$ bekezdés

${ }^{17}$ Ptk. 6:142. §

${ }^{18}$ Hidvéginé Adorján Lívia, Sáriné Simkó Ágnes: Mühibák és kártérítési perek az egészségügyben, Budapest, Medicina, 2013. 45. o.

19 2003. évi LXXXIV. törvény az egészségügyi tevékenység végzésének egyes kérdéseiről (Eütev.) 19/A. §; Ptk. 6:540. § (1) bekezdés

${ }^{20}$ a Polgári Törvénykönyvről szóló 1959. évi IV. törvény (régi Ptk.)

${ }^{21}$ régi Ptk. 350. $§(5)$ bekezdés

22 a Munka törvénykönyvéről 2012. évi I. törvény (Mt.)
} 
jogalkotás termékei, orvosi szervezetek alkotják őket, így az orvosi hivatás gyakorlására vonatkozó tudományos vélemények is részüket képezik. ${ }^{23} \mathrm{Az}$ orvoslás hivatásetikai szabályai tehát nem minősülnek jogszabálynak, megalkotásukra, vagyis a Magyar Orvosi Kamara (MOK) Etikai Kódexének megalkotására, illetve a hozzájuk kapcsolódó etikai eljárás lefolytatására azonban jogszabály, az egészségügyben müködő szakmai kamarákról szóló törvény (Ekt.) ${ }^{24}$ ad felhatalmazást.

Az orvos etikai felelösségének megállapítása esetén szankcióként alkalmazható figyelmeztetés, megrovás, pénzbírság, a tagsági viszony felfüggesztése, valamint büntetőjogi felelősség megállapítása, illetve kirívóan súlyos etikai vétség elkövetése esetén a kamarából történő kizárás is lehetséges. ${ }^{25}$ Ez utóbbi rendkívül súlyos jogkövetkezményként értékelhető, hiszen tekintettel a kötelező kamarai tagságra az orvos kamarából történő kizárása az orvosi hivatás gyakorlásának teljes ellehetetlenítését jelenti. Végső soron tehát e szankció alkalmazása a foglalkozástól eltiltással azonos eredményekhez vezet, hiszen egyrészt védi a társadalmat, másrészt kizárja annak lehetőségét, hogy az elkövető foglalkozásával összefüggésben újabb etikai vétséget (foglalkozástól eltiltás esetén büncselekményt) kövessen el. ${ }^{26} \mathrm{~A}$ büntetőjogi felelősségre vonás ultima ratio jellegére tekintettel aggályosnak tünhet egy ilyen jogkövetkezmény etikai vétség szankciójaként történő alkalmazása. Látni kell azonban, hogy a legsúlyosabb etikai büntetés alkalmazására csak kivételes esetekben van lehetőség. Ilyen például a - fentebb már említett - kiemelkedő súlyú etikai vétség elkövetése, amely már önmagában megalapozhatja a büntetőjogi felelősségre vonást.

Egészségügyi tevékenységet kizárólag az végezhet, aki tagja a szakképesítése szerint illetékes szakmai kamarának. ${ }^{27}$ E rendelkezés egyik fő indoka az etikai szabályok hatékony érvényesítése az adott hivatás gyakorlói körében. Az Etikai Kódex hatályának, illetve a MOK tagjai által választott testület, mint - egyebek mellett - szakmai felügyeleti szerv fennhatóságának valamennyi hivatásgyakorlóra való kiterjesztése az általuk végzett tevékenységgel érintett emberi élet, testi épség és egészség védelme teszi szükségessé.

\section{Az egészségügyi dolgozók büntetőjogi felelőssége}

A büntetőjogi felelősség jelentős mértékben eltér a magánjogi felelősségfajtáktól. A legszembetünőbb különbség a felelősségre vonás céljában érhető tetten, hiszen a büntetőjogi felelősségre vonás az elkövető megbüntetésre, illetve a hasonló cselekmények megelőzésére irányul, míg a magánjogi felelősség a károsultat ért károk megtérítését helyezi középpontba. ${ }^{28}$ A gyógyítás szabadsága és az orvosi hivatás gyakorlóinak jobbító szándéka elismerése mellett kijelenthető, hogy tevékenységük komoly veszéllyel

\footnotetext{
${ }^{23}$ Sótonyi Péter: Orvosi felelősség, Budapest, Semmelweis, 2006., 31. o.

24 2006. évi XCVII. törvény az egészségügyben müködő szakmai kamarákról (Ekt.)

${ }^{25}$ Ekt. 25. $\S$

${ }^{26}$ Polt Péter (szerk.): Új Btk. kommentár, I. kötet, Budapest, Nemzeti Közszolgálati és Tankönyv Kiadó, 2013. 49. o.

${ }^{27}$ Ekt. 14/A. § (1) bekezdés

${ }^{28}$ Sándor Judit: i.m. 211. o.
} 
jár, ${ }^{29}$ így a hanyag, szakszerütlen orvosi eljárás büntetőjogi szankciókkal való fenyegetése messzemenően indokolt.

A Btk. ${ }^{30}$ élet, testi épség és egészség elleni büncselekményekről szóló XV. fejezete több olyan tényállást tartalmaz, amely összefügghet az orvosi tevékenységgel, így:

- emberölés;

- öngyilkosságban közremüködés;

- magzatelhajtás;

- testi sértés;

- foglalkozás körében elkövetett veszélyeztetés.

Az egészséget veszélyeztető bűncselekmények (Btk. XVII. fejezet) körében két tényállásról kell említést tenni. Az egészségügyi termék meghamisítása alapesetének alanya bárki lehet, a törvény azonban minősített esetként rögzíti az egészségügyi dolgozóként történő elkövetést. A kuruzslás tényállása, bár a Btk. az egészséget veszélyeztető büncselekmények között szabályozza, az állampolgárok egészségének védelme mellett egy további társadalmi értéket is véd: az orvosi szakmába vetett közbizalomhoz füződő társadalmi érdek, az orvosi hivatás és tevékenység fent tárgyalt sajátosságai okán elégséges indoka egy ilyen tényállás Btk.-beli rögzítésének.

A közigazgatás rendje elleni bűncselekmények (Btk. XXXIV. fejezet) között szabályozott járványügyi szabályszegés szintén az orvosi hivatást érintő büncselekmények közé sorolandó, hiszen jogi tárgya, a közegészség védelme elsősorban az orvosok, illetve egészségügyi dolgozók tevékenysége által valósul meg.

A modern orvostudomány vívmányai időről időre új kapukat nyitnak az emberek gyógyítása mellett elkötelezett orvosok elött. Az új eszközök és eljárások teljes mértékủ elutasítása nem szolgálná az emberiség javát, tekintettel kell lenni azonban a beavatkozás alanyának jogaira, azok védelmére. ${ }^{31}$ Az 1998. évi XXII. törvény új fejezettel bővítette a hazai büntetőjog szabályanyagát, az egészségügyi beavatkozás és kutatás rendje elleni büncselekmények (XVI. fejezet) Btk.-beli rögzítése éppen a fenti okokból valósult meg. E tényállások az emberi élet, illetve a beteget megillető jogok mellett az emberi magzatot, embriót, ivarsejtet, génállományt és a holttestet is védelemben részesítik. Fontos közös jellemzőjük pedig, hogy az itt megjelölt cselekmények nem büntetendők, amennyiben az Eütv.-ben meghatározott célból végzik őket. A XVI. fejezetben meghatározott büncselekmények tehát kizárólag az orvosi tevékenységet érintő speciális törvényi tényállások, melyek a következők:

- beavatkozás az emberi génállományba;

- emberi ivarsejt tiltott felhasználása;

- születendő gyermek nemének megválasztása;

- emberen végezhető kutatás szabályainak megszegése;

- embrióval vagy ivarsejttel végezhető kutatás szabályainak megszegése;

- genetikailag megegyező emberi ivadék létrehozása;

- emberi test tiltott felhasználása.

${ }^{29}$ Kovács Gábor: Bioetika és büntetőjogi kodifikáció, Győr, Szent István Egyetem, 2008. 5. o.

30 2012. évi C. törvény a Büntető Törvénykönyvröl

${ }^{31}$ Kovács Gábor: i.m. 5. o. 
A fenti tényállások tehát nem csupán az emberi élet, testi épség és egészség fokozott védelmét biztosítják, rajtuk keresztül az orvosi tevékenység által érintett társadalmi viszonyok összessége megfelelő oltalomban részesül.

\section{A foglalkozás körében elkövetett veszélyeztetés sa- játosságai az egészségügyi ágazatban}

A tanulmány kereteire tekintettel, a törvényszöveg általános bemutatásától és a tényállási elemek mentén történő elemzésétől eltekintvén a továbbiakban egészségügyi ellátásban résztvevő tevékenységhez füződő felelősség szemszögéből való elemzésre szorítkozom.

\section{A foglalkozás körében elkövetett veszélyeztetés helye a Btk. rendszerében}

A hatályos Btk. a foglalkozás körében elkövetett veszélyeztetés tényállását az élet, a testi épség és az egészség elleni büncselekmények körében rögzíti. A rendelkezéssel védett jogi tárgy ennek megfelelően az emberi élet, testi épség, illetve egészség. Fontos viszont, hogy bár az e fejezetben szabályozott büncselekmények egy része eredményként a passzív alany sérülésének vagy halálának a tényleges bekövetkeztét követeli meg, a fejezet bizonyos feltételek mellett a veszélyhelyzet elöidézéséig tágítja a büntetőjogi jogkövetkezménnyel fenyegetett magatartások körét.

Bizonyos munkatevékenységek hanyag, szakszerütlen végzése ugyanis magában hordozza a fent felsorolt jogi tárgyak sérelmének veszélyét, így a jogalkotó az ilyen helyzetek büntetőjogi értékelésével is próbálja biztosítani e foglalkozási szabályok betartását. ${ }^{32}$ Minthogy az orvosi tevékenység a beteg egészségének megőrzésére, egészségi állapotának javítására, illetve gyakran az életveszély elhárítására irányul, az élet, testi épség és egészség veszélyeztetettsége akkor is felmerülhet, ha az ellátásban résztvevők a szakmai protokollt maradéktalanul betartva végzik tevékenységüket. Sajátos probléma továbbá, hogy a foglalkozási szabályok betartása önmagában nem biztosítja, hogy a beteg a beavatkozás során nem kerül veszélybe, számos olyan tényező befolyásolhatja negatív vagy pozitív irányba a kezelés kimenetelét, amelyre az ellátásban részt vevő orvosnak, ápolónak stb. akkor nincs ráhatása, ha a szakmai szabályok betartásával, gondosan járt el. Az egyes emberi szervezetek müködését és így egy kezelésre adott reakcióját ugyanis nem lehet minden esetben előre kiszámítani, a mechanikus szerkezetekkel ellentétben itt nem mindig érvényesülnek az ember által ismert ,játékszabályok.” Végül a leginkább szembetünő különbség a tényállás szempontjából releváns egyéb szakmai szabályokhoz képest, hogy az egészségügyi ágazatban irányadó foglalkozási szabályok - a tevékenység sajátosságaiból adódóan - nem a munkavégzés „hatókörében” tartózkodó személyeket védik, hanem azt, akit a kezelés ténylegesen érint.

\footnotetext{
32 Polt Péter (szerk.): Új Btk. kommentár, III. kötet, Budapest, Nemzeti Közszolgálati és Tankönyv Kiadó, 2013. 169. o.
} 
Az egészségügyi ágazat, illetve az itt irányadó foglalkozási szabályok sajátosságai mégsem teszik indokolttá egy, a gyógyító tevékenységhez kapcsolódó, sui generis különös részi tényállás rögzítését. A védett jogi tárgy és az elkövetési magatartás ugyanis továbbra is azonos, a szakmai szabály megszegésének társadalomra való veszélyessége pedig - álláspontom szerint - az egészségügyi ellátásban részt vevő személyek tekintetében sem fokozottabb, mint más foglalkozások, hivatások esetében, így a nagyobb tárgyi súly sem merülhet fel az önálló tényállás kimunkálásának indokaként.

\section{Az egészségügyi dolgozó, mint a foglalkozás körében elkövetett veszélyeztetés alanya}

Bár a törvény az általános alanyra utaló „,aki” kifejezést használja, az elkövetési magatartás megjelöléséből következik, hogy a büncselekmény alanya tettesi minőségben csak olyan személy lehet, aki az adott foglalkozás szabályainak hatálya alatt áll. A régi Btk. ${ }^{33}$ mentén kialakult bírói gyakorlatnak megfelelöen ${ }^{34}$ az új Btk. szövegezése ${ }^{35}$ egyértelmüvé teszi, hogy bárki alannyá válhat, aki szakképezettséget igénylő foglalkozást folytat, függetlenül attól, hogy egyébként jogosult-e erre vagy sem. ${ }^{36} \mathrm{Az}$ orvosi tevékenység kapcsán ellenben még a régi Btk. hatálya alatt kimondta a Legfelsőbb Bíróság, hogy az orvosi szakképzettséggel nem rendelkező személyek nem állnak az orvosi hivatás szabályainak hatálya alatt, így meg sem szeghetik azokat, alannyá válásuk tehát kizárt. ${ }^{37}$

A fent említett büntető elvi döntést ugyan hatályon kívül helyezték, az egészségügyi ágazati szabályozás alapján továbbra is levezethető, hogy az orvosi hivatás gyakorlása során irányadó foglalkozási szabályok megszegése csak a szakorvosok esetében alapozhatja meg a büntetőjogi felelősségre vonást. Az egészségügyi szakképzési rendszerről szóló 162/2015 (VI. 30.) Korm. rendelet 3. § (6), illetve (7) bekezdései értelmében a szakorvosjelölt tevékenységét szakorvos (tutor) felügyeli, ebböl az következik, hogy a jelöltnek a tutor ellenőrzési körébe eső tevékenységéért a tutor felel. Hasonló következtetés vonható le az egészségügyi ellátás folyamatos müködtetésének egyes szervezési kérdéseiről 47/2004. (V. 11.) ESzCsM rendelet 10. § (1) bekezdésében foglaltak alapján, mely szerint a szakorvosjelöltek kizárólag szakorvosi felügyelet mellett láthatnak el ügyeleti tevékenységet. Az Eütv. továbbá az egészségügyi ellátás személyi feltételrendszere körében az egészségügyi tevékenység önálló végzését szakképzettséghez köti. ${ }^{38}$ Ennek hiányában kizárólag felügyelet mellett lehet ilyen tevékenységet végezni, ${ }^{39}$ a felügyelet során pedig az azt ellátó személy a felügyelt sze-

\footnotetext{
33 a Büntető Törvénykönyvről szóló 1978. évi IV. törvény (régi Btk.)

34 BH 1980.5; BH 1996.7

${ }^{35}$ Az új törvény a büncselekény elkövetési magatartásként foglalkozási szabály megszegését jelöli meg, míg a régi Btk. - téves értelmezésnek teret engedve - a „foglalkozása szabályainak megszegésével" kifejezést használta.

${ }^{36}$ Polt Péter (szerk.): Új Btk. kommentár, III. kötet, Budapest, Nemzeti Közszolgálati és

Tankönyv Kiadó, 2013. 171. o.

${ }^{37}$ Legfelsőbb Bíróság V. számú büntető elvi döntés

${ }^{38}$ Eütv. 110. $\S(1)-(2)$ bekezdés

${ }^{39}$ Eütv. 110. § (3) bekezdés
} 
mély által önállóan nem végezhető szakmai tevékenységért teljes felelősséggel tartozik. ${ }^{40}$ Ezzel kapcsolatban rögzíteni kell, hogy a fenti szabály csak az olyan személyek (pl. orvostanhallgatók) tekintetében irányadó, akik az Eütv. alapján felügyelet mellett jogosultak egészségügyi tevékenységet végezni.

Napjainkban gyakori, hogy egy beteg kezelése több orvos folyamatos együttmúködésével történik, a modern orvoslás tehát felveti az orvos team felelősségének kérdését. Az úgynevezett konziliárius együttmüködés esetén, ahol az egyes tagok egyenrangúak, a felelősség szempontjából tulajdonképpen nem bír jelentőséggel az együttmüködés: valamennyi tag önállóan felel az általa előidézett veszélyhelyzetért, sérülésért stb. ${ }^{41} \mathrm{Ha}$ azonban a munkacsoport egy vezető orvos irányításával müködik, kérdés, hogy ő milyen körben felel a team tagjainak tevékenységéért. E kérdés megítélése a különböző felelősségi formákat tekintve eltérően alakul. A kártérítési kötelezettség alanya minden esetben az az egészségügyi szolgáltató, amellyel a beteg az ellátás nyújtására irányuló jogviszonyt létesítette. Elképzelhető viszont, hogy a kártérítésre kötelezett egészségügyi szolgáltató a munkáltatói, illetve megbízói regressz-igényének érvényesítése során -az őt a team irányításával összefüggésben terhelő kötelezettségek függvényében - csak a csoport vezetőjét vonja felelösségre. A foglalkozás körében elkövetett veszélyeztetés elkövetésének megállapíthatósága tekintetében ezzel szemben nincs jelentősége a munkacsoport irányításával kapcsolatos kötelezettségeknek. A magatartás csak akkor tényállásszerü, ha az beteg életét, testi épségét, illetve egészségét a közvetlen veszély vagy a testi sérülés stb. valamely foglalkozási szabály megszegése nyomán következik be. Ha tehát a team egyik tagja által megvalósított szakmai szabályszegéssel összefüggésben a tényállásban meghatározott eredmény bekövetkezik, az érintett orvos büntethetöségét nem zárhatja ki az, hogy a munkacsoport tevékenységét egy másik személy irányította. A munkacsoportban dolgozó szakorvosokra ugyanúgy vonatkoznak az általános, illetve a területüket érintő foglalkozási szabályok, mintha önállóan végeznék a kezelést. A vezető orvos büntetőjogi felelőssége a team tagja által megvalósított szabályszegéssel összefüggésben csak akkor állapítható meg, ha valamely, reá vonatkozó foglalkozási szabály megszegése felmerül. Az azonban, hogy a munkacsoport vezetője a team minden lépését nyomon kövesse, nem tünik életszerünek, hiszen e módszert éppen a munkamegosztás miatt alkalmazzák. Ennek kapcsán jelentőséggel bírhat az Eütv. 77. $\S$ (3) bekezdésében rögzített, az ellátásban résztvevőktől elvárható gondosság követelménye. Ha ugyanis a csoport vezetőjének, vagy a team bármely tagjának észlelnie kellett volna a szabályszegést, illetve az ezzel összefüggésben potenciálisan felmerülő veszélyhelyzetet, a fenti gondossági követelmény, mint foglalkozási szabály megsértése miatt az ő felelösségre vonásuk is felmerülhet.

\section{„Orvosi múhibák” napjainkban: a foglalkozás körében elkövetett veszélyezte- tés elkövetési magatartása és más felelősségi formák}

A köznyelv az egészségügyi dolgozók felelősségre vonására irányuló büntetőeljárásokat és polgári pereket mühibaperekként ismeri. A közegészségügy rendezéséröl

\footnotetext{
${ }^{40}$ Eütv. 110. $\S(15)$ bekezdés

${ }^{41}$ Molnár Gábor: Egészségügyi dolgozók büntetőjogi felelőssége, https://www.drportal.hu/hir.php?szid=99\&tema=67\&hid=22044 (letöltés időpontja: 2017. június 9.)
} 
szóló 1876. évi XIV. törvény az orvos „műhibákért” való felelősségének deklarálásával rakta le az egészségügyi tevékenységért való felelősség jogi alapjait, orvosi mühiba azonban napjainkban már nem létező jogi fogalom. Amíg az orvosi mühiba kifejezés túlélte az azóta eltelt százötven évet, addig az egészségügyi tevékenységgel összefüggő felelősség szabályozása az orvos felelősségének deklarálásától egy sajátos és meglehetősen összetett rendszer kialakításáig jutott.

A Btk. a foglalkozás körében elkövetett veszélyeztetés tényállásán keresztül továbbra is kifejezetten az egészségügyi dolgozók által tevékenységük során elkövetett hibákat, az egészségügyi dolgozók vonatkozásában irányadó foglalkozási szabályok megszegését szankcionálja. A Btk. nem ad eligazítást a tekintetben, hogy mely szabályok tekinthetők egészségügyi foglalkozási szabálynak. ${ }^{42}$ Az orvosi foglalkozás szabályait a jogszabályok nem rendezik teljes körüen. A jogi normák mellett foglalkozási szabálynak tekintendők a szakma rendeletekbe, utasításokba foglaltan írott, vagy szokásszerü, íratlan szabályai. ${ }^{43}$ Fontos azonban, hogy a fenti normák megszegése önmagában nem alapozza meg a büntetőjogi felelösségre vonást, a foglalkozás körében elkövetett veszélyeztetés ugyanis materiális büncselekmény, így befejezetté válásához az szükséges, hogy az elkövető másnak vagy másoknak közvetlen veszélyt, vagy testi sértést okozzon. ${ }^{44}$

Kétségtelen, hogy a betegnek a foglalkozási szabály megsértésével összefüggésben felmerülő egészségkárosodása a bünösség megállapítása mellett kártérítési kötelezettséget és etikai felelősségre vonást is eredményezhet, ezek azonban nem feltétlenül járnak együtt. Az egészségügyi szolgáltató kártérítési felelőssége, illetve sérelemdíj fizetési kötelezettsége ugyanis felmerülhet az ellátásban részt vevő személyekre vonatkozó foglalkozási szabályok megsértése hiányában is. Az egyes kezelésekkel, beavatkozásokkal összefüggésben számos olyan, a kezelést nyújtó orvos tevékenységétől független kockázati tényező merülhet fel, amelyek a Btk. 165. § (1) bekezdésében felsorolt eredményekhez vezethetnek. Amennyiben a beteg tájékoztatása ezekre nem terjedt ki, ennél fogva pedig ezek ismerete hiányában adta meg a beavatkozáshoz való hozzájárulását, a tájékoztatáshoz való jog ${ }^{45}$ sérelme megalapozza az egészségügyi szolgáltató kártérítési/sérelemdíj fizetési kötelezettségét, akkor is, ha a mütéti vagy egyéb kockázat az eljáró orvosok szakmai szabályszegése nélkül következett be. Ilyen esetben azonban nem valósul meg foglalkozás körében elkövetett veszélyeztetés, ugyanis a leggondosabb eljárás mellett is felléphetnek egészségügyi komplikációk, szövődmények, ezek azonban nem lépik túl az általános kezelési kockázat kereteit, így társadalomra való veszélyességröl sem beszélhetünk. Ha azonban az orvos helytelenül választja meg az alkalmazandó eljárást, vagy annak müveleteit nem a protokollnak megfelelően végzi, szakmai szabályszegést követ el. E körben felmerül még a diagnosztikai tévedés kérdése, mellyel kapcsolatban kijelenthető, hogy önmagában

\footnotetext{
42 Madai Sándor: „Nem tudunk csodát tenni” - Gondolatok az orvosi műhiba büntetőjogi megítéléséhez, Med et Jur 2011. 1. évfolyam 4. szám, 28. o.

${ }^{43}$ BH 2002.129.

${ }^{44}$ Horváth Tibor, Lévai Miklós (szerk.): Magyar büntetőjog különös rész, Budapest, Complex, 2009. 104. o.

${ }^{45}$ Eütv. 13. $§(1)$ bekezdés
} 
nem jelent szakmai szabályszegést, ${ }^{46}$ ha viszont a diagnózis felállításához szükséges vizsgálatok hiányosak, vagy azokat nem a szakmai elöírásoknak megfelelően végzik, megállapítható az orvos büntetőjogi felelőssége.

Az egészségügyi szolgáltatással összefüggésben elszenvedett kárért való felelősség általában a beteg egészségkárosodásának tényleges bekövetkezése esetén kerül megállapításra, a foglalkozás körében elkövetett veszélyeztetés tényállása ezzel szemben megelégszik a veszélyhelyzet előidézésével. A bírói gyakorlat szerint azonban az egészséghez és testi épséghez való jog akkor is sérül, ha a beavatkozást végző orvos a beteg életveszélyes állapotát idézi elö, akkor is, ha a beteg szövődmény nélkül gyógyul, ${ }^{47}$ így a veszélyhelyzet bekövetkezte a magánjogi felelősséget is megalapozhatja.

A foglalkozási szabályok megszegése az egészségügyi dolgozó büntetőjogi felelősségének megállapítása mellett magánjogi és etikai felelősségre vonáshoz is vezethet. Kérdés tehát, hogy ha a kártérítési felelősség mellett egyazon jogalapon a foglalkozás körében elkövetett veszélyeztetés megállapítása is lehetséges, utóbbi miért marad el az esetek többségében.

Bár a foglalkozás körében elkövetett veszélyeztetés közvádra üldözendő büncselekmény, a nyomozóhatóság többnyire csak a sértett, illetve a hozzátartozók feljelentése nyomán szerez tudomást az ilyen esetekről. Személyes gyakorlati tapasztalataim azt mutatják, hogy az egészségügyi szolgáltatással összefüggésben kárt szenvedett betegek, az ezzel kapcsolatos igényeik magánjogi úton történő érvényesítése mellett nem kívánnak élni a felelősségre vonás egyéb eszközeivel. Megjegyzendő továbbá, hogy míg az egészségügyi szolgáltatással összefüggő kártérítési igény öt, addig a foglalkozás körében elkövetett veszélyeztetés alapesete egy év alatt évül el, a büntethetőség tehát a legtöbb esetben megszünik, mire a sértett egyáltalán megfontolja a felelősségre vonás kezdeményezésének lehetőségét. Ezzel összefüggésben kiemelendő továbbá, hogy az egészségügyi szolgáltatással kapcsolatos kártérítési perekben a bírói gyakorlat ${ }^{48}$ az okozati összefüggés tekintetében, a bizonyítás Pp.-beli szabályaitól eltérően mentesíti a Felperest a bizonyítási teher alól, ha ugyanis a szakismeretekkel nem rendelkező beteget orvosi szakkérdések tekintetében terhelné bizonyítási kötelezettség, az igényérvényesítés komoly nehézségekbe ütközne. A Felperesnek - a kár összegén kívül - csak azt kell bizonyítania, hogy a kár, illetve személyiségi jogi sérelem az egészségügyi ellátás igénybevétele során következett be. Az egészségügyi szolgáltatónak kell tehát bizonyítania, hogy a lehetséges szakmai intézkedéseket megtette, és a károsodás ennek ellenére, vagy ettől függetlenül következett be. ${ }^{49}$ A büntetőeljárásban ezzel szemben a vádlót terheli a vád bizonyítása, ${ }^{50}$ amely a foglalkozási szabály megszegésével, illetve az eredménnyel való okozati összefüggéssel kapcsolatos szakkérdések miatt - még megfelelő szakértői vélemény birtokában is - meglehetősen nehézkes.

\footnotetext{
${ }^{46}$ Polt Péter (szerk.): i.m. 179. o.

${ }^{47} \mathrm{EH} 1999.15$

${ }^{48}$ BH+ 2011.3.109; EBH 2006.1506; LB Pfv. III. 22.099/2000; Debreceni Ítélőtábla Pf. I. $20.723 / 2009$.

${ }^{49}$ Dósa Ágnes: Az orvos kártérítési felelőssége, HVG-ORAC, Budapest, 2010. 116. o.

${ }^{50}$ Be. 4. § (1)-(2) bekezdés
} 


\section{Összegző gondolatok}

Az orvosi tevékenység társadalmi és jogi megítélése a rendszerváltást követően gyökeres változásokon ment keresztül. Az orvos napjainkban már nem a „fehér köpenyes varázsló”, hivatásának gyakorlása során immár nem csupán az íratlan szakmai szabályoknak és az etikai kódexnek kell megfelelnie. Ellenkezőleg, az egészségügyi tevékenységhez egy meglehetősen sajátos, szerteágazó felelősségi rendszer társul. Az önálló etikai felelősségi szabályok és a magánjogi felelősséghez kapcsolódó szigorú gondossági mérce az élet, testi épség és egészség, mint kiemelten védendő társadalmi értékek oltalmát szolgálják.

A fenti jogi tárgyak védelme viszont csak a hanyag, szakszerütlen egészségügyi tevékenység büntetőjogi fenyegetésével együtt lehet teljes. A foglalkozás körében elkövetett veszélyeztetés, bár nem kifejezetten az egészségügyi tevékenységhez kapcsolódik, kerettényállásként megfelelően szolgálja a fenti célokat.

Ami pedig az egészségügyi tevékenység felelősségi rendszerét illeti, az egészségügyi szolgáltatásokkal kapcsolatos kártérítési perekhez kapcsolódó bírói gyakorlat és az ennek mentén kialakult speciális szabályozás lehetővé teszi a betegek igényérvényesítését, az etikai normák biztosítják a szakmai kontrollt, a büntetőjog pedig ténylegesen ultima ratio szerepet tölt be ebben a körben.

\section{Felhasznált Irodalom}

1. Dósa Ágnes: Az orvos kártérítési felelőssége, HVG-ORAC, Budapest, 2010.

2. Elliot Aronson: A társas lény, Budapest, KJK, 2001.

3. Eörsi Gyula: A jogi felelősség alapproblémái, a polgári jogi felelősség, Budapest, Akadémiai Kiadó, 1961.

4. Hidvéginé Adorján Lívia, Sáriné Simkó Ágnes: Mühibák és kártérítési perek az egészségügyben, Budapest, Medicina, 2013.

5. Horváth Tibor, Lévai Miklós (szerk.): Magyar büntetőjog különös rész, Budapest, Complex, 2009.

6. Jobbágyi Gábor: Orvosi jog, Szent István Társulat, Budapest, 2010.

7. Kovács Gábor: Bioetika és büntetőjogi kodifikáció, Győr, Szent István Egyetem, 2008.

8. Madai Sándor: „Nem tudunk csodát tenni” - Gondolatok az orvosi mühiba büntetőjogi megítéléséhez, Med et Jur 2011. 1. évfolyam 4. szám

9. Molnár Gábor: Egészségügyi dolgozók büntetőjogi felelőssége, https://www.drportal.hu/hir.php?szid=99\&tema=67\&hid=22044 (letöltés idöpontja: 2017. június 9.)

10. Polt Péter (szerk.): Új Btk. kommentár, I. kötet, Budapest, Nemzeti Közszolgálati és Tankönyv Kiadó, 2013.

11. Polt Péter (szerk.): Új Btk. kommentár, III. kötet, Budapest, Nemzeti Közszolgálati és Tankönyv Kiadó, 2013.

12. Sándor Judit: Gyógyítás és ítélkezés, Budapest, Medicina, 1997.

13. Sótonyi Péter: Orvosi felelősség, Budapest, Semmelweis, 2006. 